\title{
Community structure of rhodolith-forming beds on the central Brazilian continental shelf
}

\author{
Alexandre B. Villas-Boas • Rafael Riosmena-Rodriguez • \\ Marcia Abreu de Oliveira Figueiredo
}

Received: 30 November 2012/Revised: 24 June 2013/Accepted: 6 July 2013/Published online: 24 July 2013

(C) Springer-Verlag Berlin Heidelberg and AWI 2013

\begin{abstract}
The community structure of rhodoliths beds in the central Brazilian continental shelf was studied under the hypothesis that nongeniculate coralline algae are the major contributors of the individual rhodoliths. Samples were collected from five localities within a single area at 17-18 m depth. At each locality, rhodoliths were collected in 10 random quadrat samples along a 20 -m transect. Our results show that dead cores of rhodoliths were significantly composed by nongeniculate coralline red algae rather than bryozoans, corals, or inorganic material. The live outer layers of the rhodoliths are composed mainly of 7 species of nongeniculate red coralline algae (Lithophyllum coralline, L. johansenii, L. depressum, L. stictaeformis, Neogoniolithon brassica-florida, Spongites fruticosus, and Lithothamnion muellerii) associated with other encrusting organisms such as bryozoans, sponges, corals, barnacles, and Peyssonnelia red algae. Significant differences were found in the proportion of Lithophyllum species in relation to other red coralline algae found in this study. Our results show that on the Brazilian continental shelf, the rhodolith-
\end{abstract}

Communicated by Weinberger.

A. B. Villas-Boas - M. A. de Oliveira Figueiredo Programa de Pós-Graduação em Ciências Biológicas-Botânica, Museu Nacional, Universidade Federal do Rio de Janeiro, Quinta da Boa Vista S/N, Rio de Janeiro CEP 20940-040, Brazil

A. B. Villas-Boas - M. A. de Oliveira Figueiredo Instituto de Pesquisas Jardim Botânico do Rio de Janeiro, Rua Pacheco Leão 915, Rio de Janeiro, RJ 22460-030, Brazil

R. Riosmena-Rodriguez ( $\square$ )

Programa de Investigación en Botánica Marina, Departamento de Biología Marina, Universidad Autónoma de Baja California Sur, km 5.5 carr al sur, $23080 \mathrm{La} \mathrm{Paz,} \mathrm{BCS,} \mathrm{Mexico}$

e-mail: riosmena@uabcs.mx forming species are quite higher in size than in any other studied areas in the world. There was no difference in the proportion of live-to-dead rhodolith materials, suggesting an old bed deposit. Also, the amount of calcium carbonate material in the specimens is relevant to take in account in terms of the $\mathrm{CO}_{2}$ balance worldwide.

Keywords Coralline red algae - Community structure · Encrusting organisms $\cdot$ Rhodolith bed

\section{Introduction}

Rhodolith beds support subtidal communities around the world relevant in many ecological processes (Foster 2001). The rhodolith skeleton is composed of carbonate components, commonly encrusted, abraded, and bioeroded (Checconi et al. 2006). Rhodolith sphericity (Bosence 1976; Foster et al. 1997), branch density (Steller and Foster 1995; Basso et al. 2009), and species composition (Steller et al. 2003, 2009) are influenced by water motion and depth. Substratum stability can be one of the main forces that drive rhodolith community composition, as demonstrated for some other environments (Littler and Littler 1984). Consequently, one or more encrusting species may become part of an individual rhodolith (Bosellini and Ginsburg 1971; Bosence 1983a, b, c; ReyesBonila et al. 1997; James et al. 2006). In any of the above cases, live material is fixed on the most external pigmented layer (Steller et al. 2003), strongly suggesting that proportions of live and dead material are unequal (Bahia et al. 2010). The settlement and survival of competing organisms can be limited by negative interactions with the coralline algae (Figueiredo et al. 1997; Villas-Boas and Figueiredo 2004). 
The structure of individual rhodoliths may vary from being composed of a single coralline species (RiosmenaRodriguez et al. 1999, 2010; Steller et al. 2003) to a structure with a composition of multiple species termed "boxwork rhodolith" Bosence (1983a, b; Basso 1998; Baarli et al. 2012). This structure can result from the fragmentation of corals, reef rock, bivalve, and gastropod shells or coralline algae alone (Bosence 1985; Piller and Rasser 1996). Little is known about their community structure and whether beds are dominantly composed by individual or multispecific rhodoliths.

Our present knowledge of species composition within rhodolith beds is limited to few studies in European waters (Basso 1998; Birkett 1998; Sciberras et al. 2009), the Red Sea (Piller and Rasser 1996), the Gulf of California (Steller et al. 2003, Yabur-Pacheco and Riosmena-Rodriguez 2007), Canada (Gagnon et al. 2012), Southern Australia (Harvey and Bird 2008), and New Zealand (Nelson 2012). In the North Atlantic Ocean, some of the most common sessile elements within the rhodolith framework are bivalves, gastropods, serpulids, bryozoans, foraminifera, sponges, and tunicates (e.g., Florida Keys in Bosence 1985) with only limited data available about their relative abundance. In the South Atlantic, however, little is known about the relative abundance of encrusting organisms on rhodoliths, although their relevance for seaweed richness and biomass has been shown (Riul et al. 2009).

One of the most extensive areas for rhodolith beds in the world is on the Brazilian continental shelf ranging from $2^{\circ} \mathrm{N}$ to $25^{\circ} \mathrm{S}$ (Kempf 1970; Foster 2001), with a coastal length of $4,000 \mathrm{~km}$. It has been documented as one of the most important calcium carbonate-producing bio-factories in the tropical South Atlantic (Amado-Filho et al. 2012c). Most of the known rhodolith beds in Brazilian waters are situated between 20- and 100-m depth (Kempf 1970), most of the known beds are in the north part of the country (Testa 1997; Amado-Filho et al. 2012a, b), and a single bed is at the south end of Brazil(Gherardi 2004; Pereira-Filho et al. 2012). However, little information is available about the composition of encrusting communities that build these rhodolith beds. Therefore, our goals are to (1) describe rhodolith-forming community structure; (2) identify the proportion of the main coralline algae genera that build rhodoliths; (3) determine the proportion of live and dead material in rhodoliths.

\section{Materials and methods}

\section{Study area}

The studied localities are located in Banco do Índio (BI) in Espírito Santo State. This state has a coastline of $421 \mathrm{~km}$ on the central Brazilian continental shelf (Fig. 1). Winds are predominantly and stronger from the east to northeast directions. However, southeastern winds are commonly associated with storms from June to September. Heavy rainfall occurs from October to January. The continental

Fig. 1 Study site and localities of the studied rhodolith bed (Banco do Indio) on the central Brazilian continental shelf

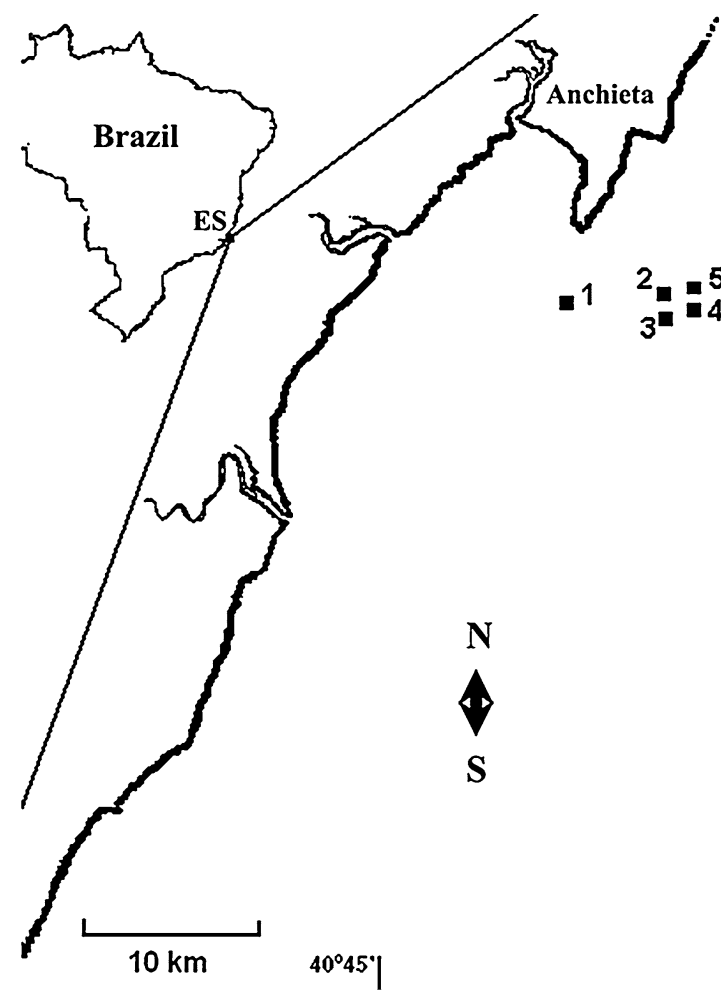

$20^{\circ} \overline{11}$ 
Table 1 Location and depth of the sample sites at central Brazilian continental shelf

\begin{tabular}{lll}
\hline Sites & Location & Depth $(\mathrm{m})$ \\
\hline 1 & $20^{\circ} 54^{\prime} 09^{\prime \prime} \mathrm{S}-40^{\circ} 38^{\prime} 46^{\prime \prime} \mathrm{W}$ & 18 \\
2 & $20^{\circ} 54^{\prime} 14^{\prime \prime} \mathrm{S}-40^{\circ} 34^{\prime} 50^{\prime \prime} \mathrm{W}$ & 18.3 \\
3 & $20^{\circ} 54^{\prime} 12^{\prime \prime} \mathrm{S}-40^{\circ} 34^{\prime} 50^{\prime \prime} \mathrm{W}$ & 18.8 \\
4 & $20^{\circ} 54^{\prime} 32^{\prime \prime} \mathrm{S}-40^{\circ} 35^{\prime} 05^{\prime \prime} \mathrm{W}$ & 18 \\
5 & $20^{\circ} 53^{\prime} 23^{\prime \prime} \mathrm{S}-40^{\circ} 34^{\prime} 07^{\prime \prime} \mathrm{W}$ & 17.7 \\
\hline
\end{tabular}

shelf of Espírito Santo is influenced by the Brazilian Current that runs along the coast from north to south. This current is described in the literature as a weaker current compared to the Gulf Current in the North Atlantic (Silveira et al. 2000).The studied beds are situated at $18-\mathrm{m}$ depth and $16 \mathrm{~km}$ offshore (Fig. 1; Table 1). Local oceanographic conditions feature high-speed currents at the sea surface, but slow bottom currents. Maximum at the bottom irradiance levels is about $800 \mu \mathrm{mol} \mathrm{m} \mathrm{m}^{-2} \mathrm{~s}^{-1}$ on the sea surface and $200 \mu \mathrm{mol} \mathrm{m} \mathrm{m}^{-2} \mathrm{~s}^{-1}$ at the bottom with occasional turbidity. Average water temperature is $27^{\circ} \mathrm{C}$ at the surface and $20-21{ }^{\circ} \mathrm{C}$ at the bottom, with a salinity of $37 \%$.

\section{Sampling}

Samples were collected in the fall (April 2005). The five studied localities are separated by a distance of 200-1,000 m from each other (Fig. 1). SCUBA was used to cover a standard area of $30 \mathrm{~m}^{2}$ at each site by diving. Ten random $0.25 \mathrm{~m}^{2}$ quadrats in a $20-\mathrm{m}$ transect were surveyed at each site, in total 50 quadrants. All rhodoliths were collected from each quadrat in order to measure size and sphericity and to quantify the relative abundance of coralline algae and other associated encrusting organisms.

\section{Rhodolith morphology}

Sampled rhodoliths were measured and classified into five size classes for volume: $1=(0.1-100 \mathrm{ml}) ; 2=$ $(101-200 \mathrm{ml}) ; 3=(201-300 \mathrm{ml}) ; 4=(301-400 \mathrm{ml}) ; 5=$ $(401-500 \mathrm{ml})$. The average size was also estimated based on the largest diameter and dry mass. Rhodolith shapes were analyzed following the classification according to Sneed and Folk (1958). Their degree of sphericity was estimated based on three diameters, where " $\mathrm{S}$ " is equivalent to the smallest rhodolith diameter, "I" refers to the intermediate measure, and " $\mathrm{L}$ " to the largest measure. These data were analyzed by the Tri-Plot Program (Excel, Microsoft) using the formulas: $S / L ; L-I / L-S$ and $\left(S^{2} / L I\right)^{1 / 3}$ which determines the degree of sphericity for each rhodolith sample and represents them on a triangular graph for each sampled site.
Community structure

Live encrusting organisms from the superficial layer were taken from the rhodolith "boxwork" core. These were separated into high-order taxonomic groups and ovendried at $60{ }^{\circ} \mathrm{C}$ prior to dry mass measurement. Samples were not decalcified in order to estimate their contribution to the bulk of the rhodolith structure. The biomass of each group was converted to a percentage of total rhodolith mass.

Taxonomic identification of nongeniculate coralline red algae was based on the paper by Villas-Boas et al. (2009) for Lithophyllum. The frequency of nongeniculate coralline algae (NG) genera (in the case of Lithophyllum, all four species were commonly present in the samples, and in the case of Masthoporoideae and Melobesioideae, one species was identified) was estimated for each rhodolith.

Normality and homoscedasticity were tested after percentage data were arcsin-transformed before analysis of variance (ANOVA) was used to test differences among organism abundance by groups. The Tukey test was used to detect differences among means when the ANOVA results with a probability of 0.05 (Zar 1984). Pearson's correlation was used to examine the association between the abundance of calcareous algae and other groups of encrusting organisms.

\section{Results}

Rhodolith morphology

A total of 50 individual rhodoliths were evaluated on site. The average and range size of rhodoliths in all the studied sites were (4)-10-(24) $\mathrm{cm}$ based on the largest diameter. The dry mass was (27)-162-(886) g, and the volume was (10)-165 (500) ml. Spherical forms included the compact, compact foliose, and compact elongated. These forms were composed by one nongeniculate species (Fig. 2a). Boxwork were composed by up to four nongeniculate genera (and one main species each) plus other encrusting organisms (Fig. 2b, c).

In most studied sites, the smallest size class (up to $100 \mathrm{ml}$ ) dominated except site 4 where there was also a high frequency of the size class immediately above (up to $200 \mathrm{ml}$ ). At site 5, there was no difference among size classes (Fig. 3: 1a to 5a).

In relation to degree of rhodolith sphericity, there was a high frequency of foliose forms ( $70 \%$ ) at sites $1,3,4$, and 5 , and only in site 2 , there was a high frequency of both spherical and foliose forms (Fig. 3: $1 \mathrm{~b}$ to $5 \mathrm{~b}$ ). 

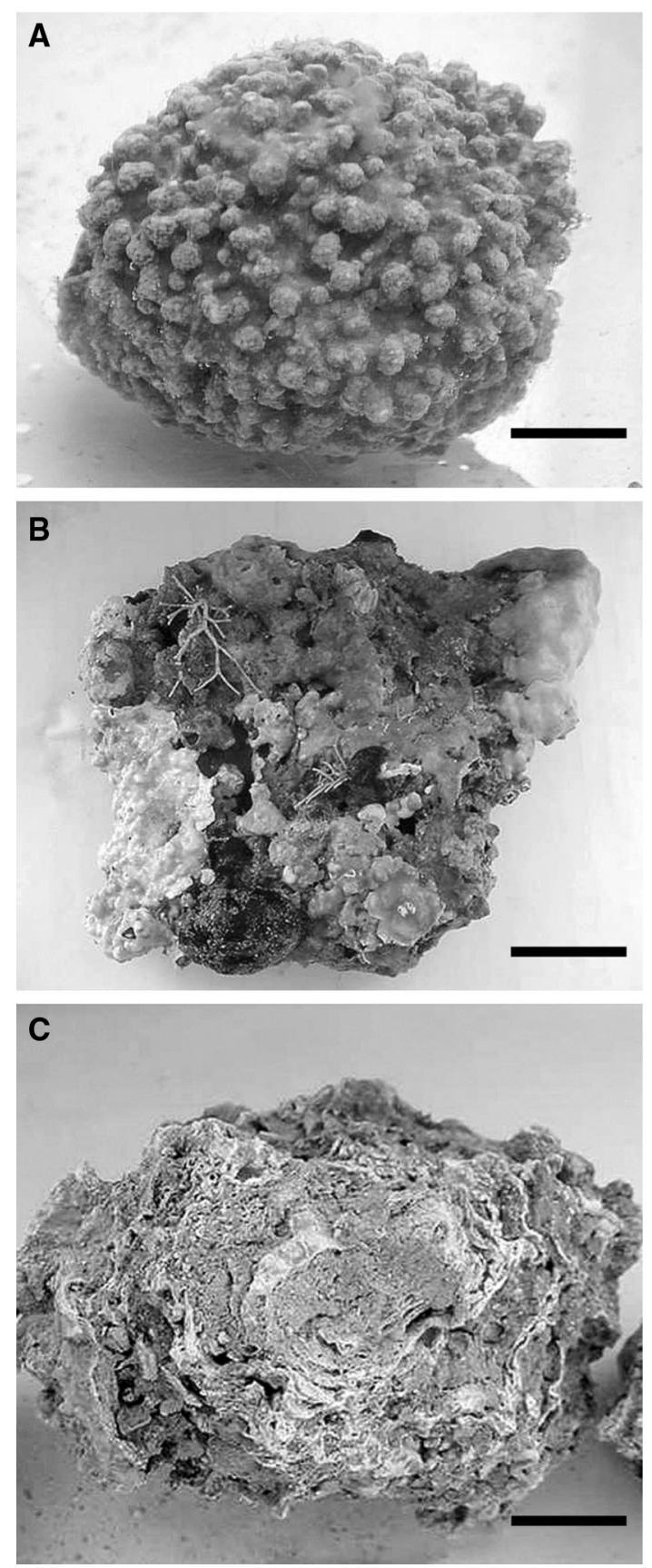

Fig. 2 Individual rhodolith forms, according to Bosence (1983a, b, c), found in the studied bed: a spherical and monospecific rhodolith. Scale bars $2 \mathrm{~cm}$; b "boxwork" rhodolith composing by up to four genera. Scale bars $3 \mathrm{~cm}$; c "boxwork" rhodolith showing the concentric nature of core material. Scale bars $1.7 \mathrm{~cm}$

\section{Community structure}

The studied area is mostly composed by large, foliose, and nongeniculate multispecific rhodoliths with a "boxwork" internal structure and by smaller, spherical, and monospecific rhodoliths. Lithophyllum was the most frequent nongeniculate genus, including four species (Lithophyllum coralline, L. johansenii, L. depressum, L. stictaeformis), followed in frequency by Neogoniolithon brassica-florida. Both genera were present in at least half of the rhodolith samples. Spongites fruticulosus and Lithothamnion muellerii were less frequent species (Fig. 4). Among the analyzed rhodoliths, $54 \%$ were built by two nongeniculate genera, $32 \%$ had only one genus, $13 \%$ had three genera, and $1 \%$ had four genera. All the material was examined based on external features confirmed by thin histological sections.

Comparing live encrusting organisms on the surface with the dead core of rhodoliths, it was observed that half the dry mass was composed of live organisms (including carbonate skeletons, shells, and sponge spicules) and the other half by a core formed by dead nongeniculate, dead bryozoans, dead corals, and mineral substrata (Fig. 2c). There was no significant difference between the percentage of live and dead materials that built rhodoliths at most studied sites (ANOVA, $p>0.05$ ), except for site 5 (ANOVA, $p=0.005$ ) (Fig. 5).

The abundance of live encrusting organisms and their contribution to rhodolith bulk structures differed significantly among rhodoliths, independent of the studied site. Nongeniculate coralline red algae were the dominant group of organisms in the rhodolith composition. Bryozoans and crustaceans (barnacles) were less abundant groups, considering that their material represents $3 \%$ or less of the total biomass against $5 \%$ of nongeniculate coralline algae. Sponges were found but represented the least important group. There was a significant difference in encrusting organism's dry mass among studied sites and among all groups of organism, independent of each other (Fig. 6; Table 2). However, there was no significant correlation between nongeniculate coralline red algae abundance and other encrusting groups of organism (Pearson's correlation, $p=0.14$ for sponges; $p=0.07$ for bryozoans; and $p=0.2$ for crustaceans). Among rare organisms, mollusk bivalves, corals, and the red calcareous alga Peyssonnelia were found that together represented $1 \%$ of the total biomass among all the studied sites.

\section{Discussion}

The results have shown that nongeniculate coralline red algae are the most abundant external layer component in the rhodolith structure. Other studies mentioned the presence of other encrusting organisms; however, they did not estimate their relative contributions to the rhodolith composition (Bosence 1985; Basso 1998; Prager and Ginsburg 1989; Gherardi 2004). In the studied area, spherical rhodoliths were usually composed of only one nongeniculate coralline red algal species and genus, while foliose 
Fig. 3 Size class volume frequency (a) and sphericity degree (b) of rhodoliths among studied sites $(1-5 ; n=10$ per site)
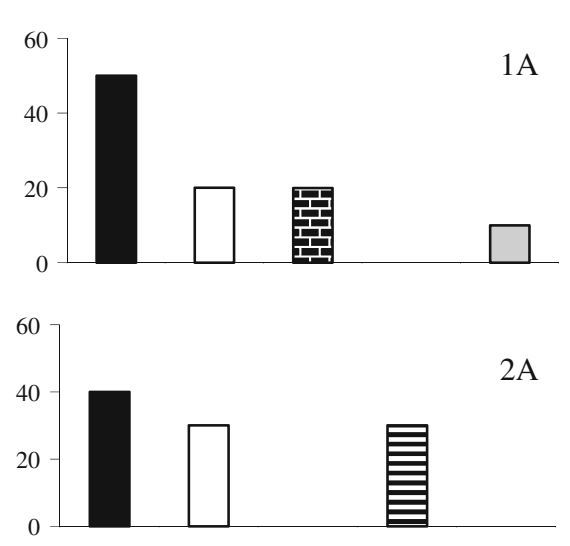

Discoidal

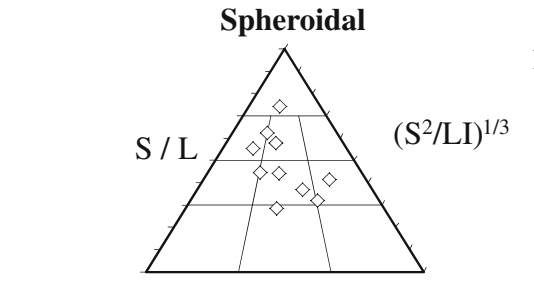

1B

$(\mathrm{L}-\mathrm{I}) /(\mathrm{L}-\mathrm{S})$

Ellipsoidal
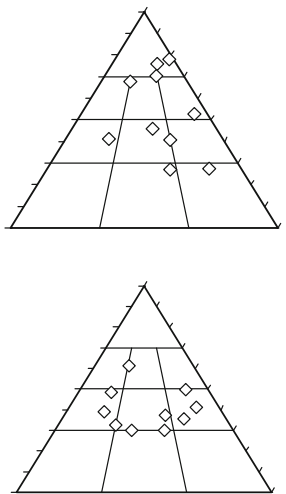

3B
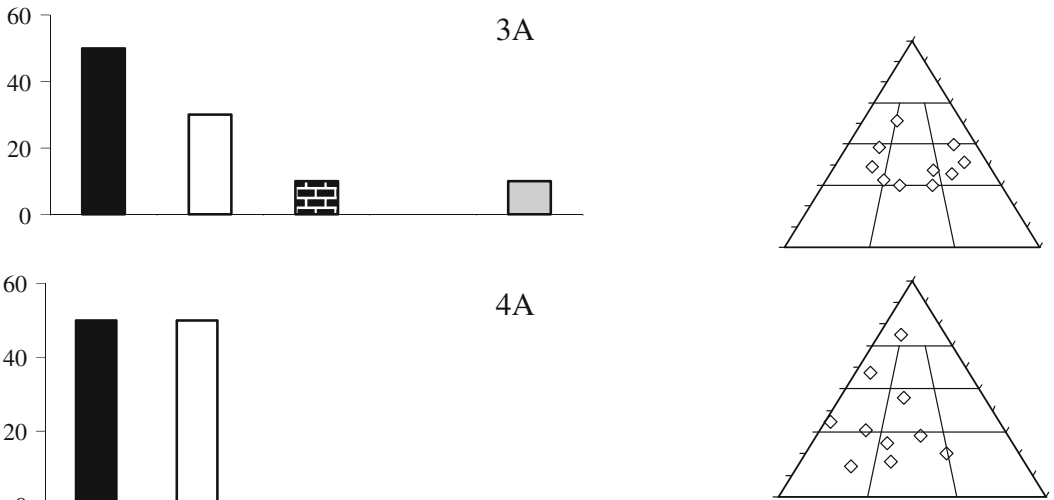

4B
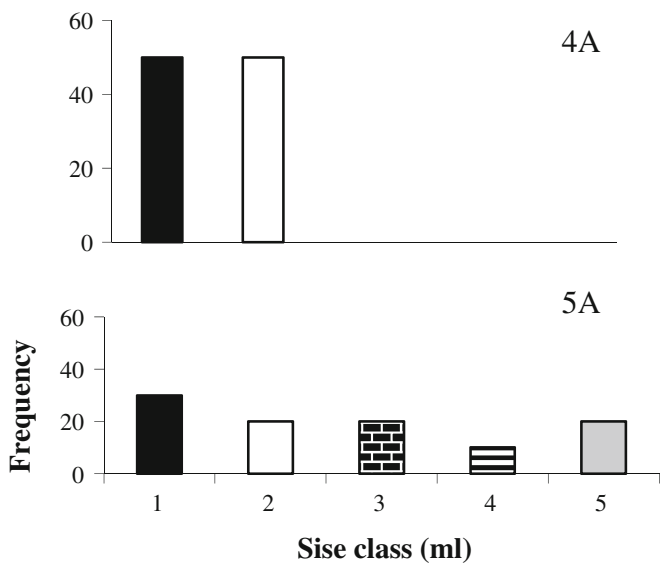

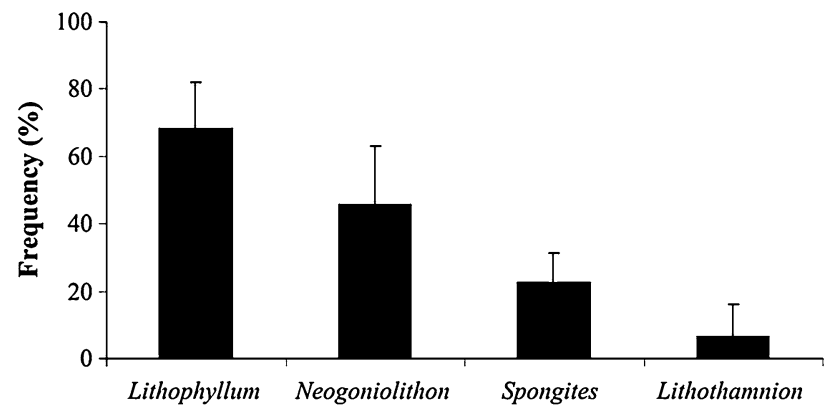

Fig. 4 Mean and std of frequency of each coralline algal genus found in rhodoliths $(n=50)$

rhodoliths were composed of up to four nongeniculate coralline red algal genera. In general, foliose rhodoliths composed of two or more nongeniculate coralline red genera and other encrusting organisms were the majority in this bed. Prager and Ginsburg (1989) found that sites with strong bottom currents and wave action tend to be

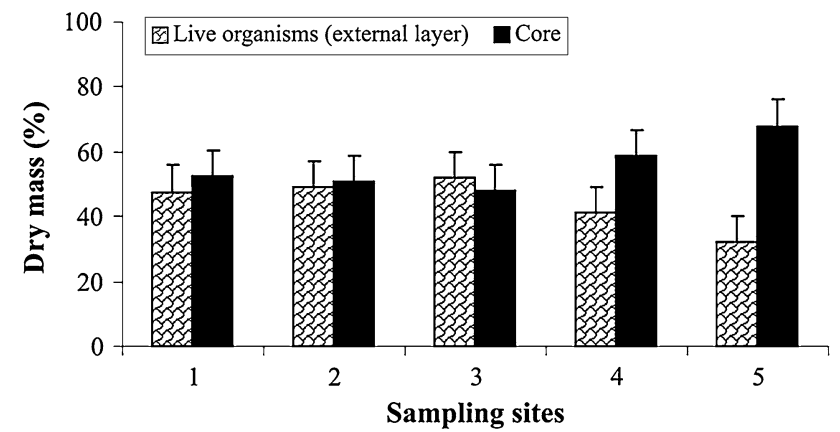

Fig. 5 Mean and std of dry mass content of live and dead material in the boxwork rhodolith samples

dominated by spherical rhodoliths, while sites with slower bottom currents tend to induce the formation of foliose shapes. However, other more recent studies have shown that water movement is not always relevant for rhodolith shape (Foster et al. 1997; Marrack 1999). Rhodoliths with 

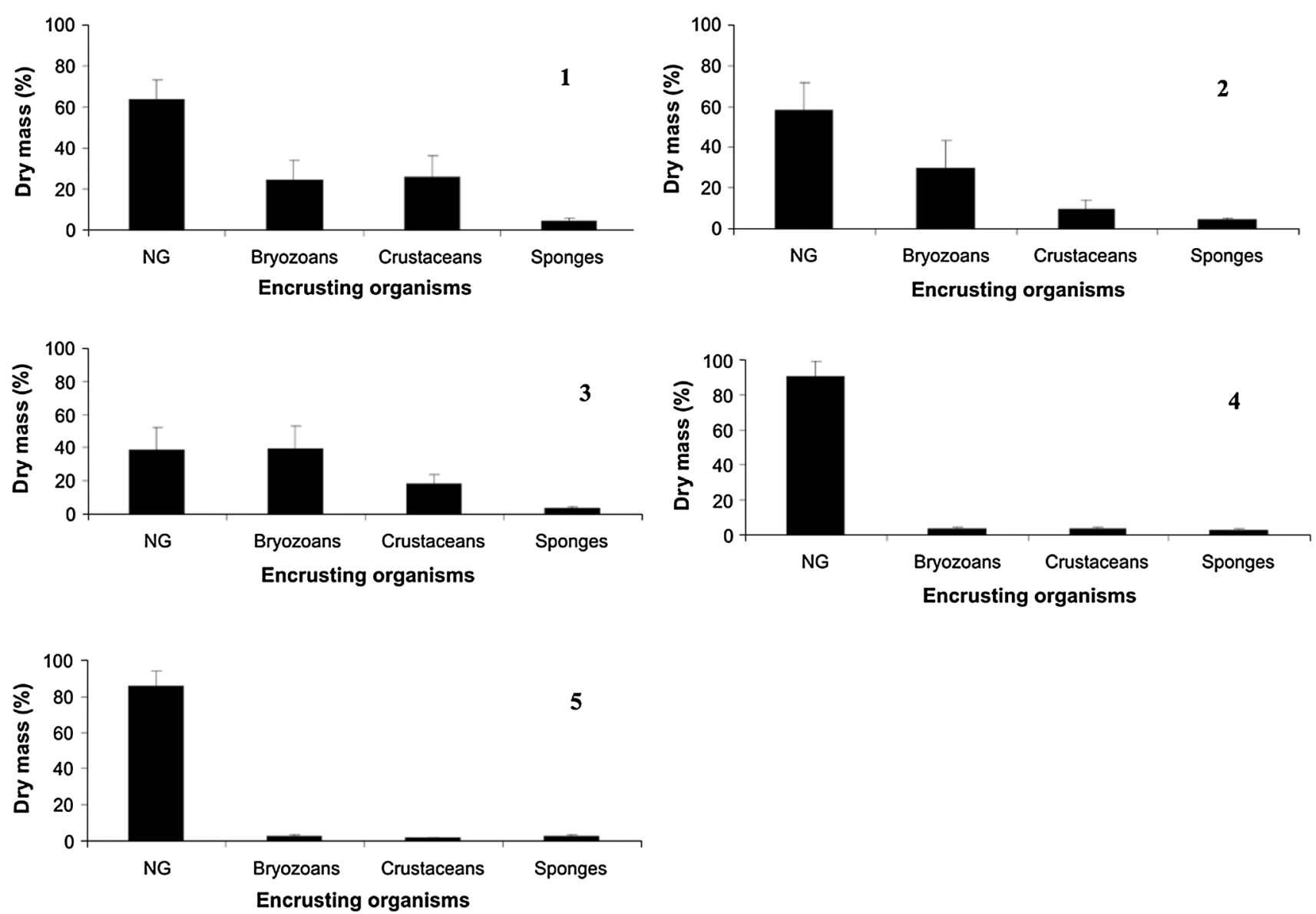

Fig. 6 Mean and std of abundance of encrusting organism groups in the composition of external layers of rhodoliths at five studied sites (1-5). (NG) nongeniculate coralline algae

Table 2 Analysis of variance for the dry mass of encrusting organisms at the five studied sites (S) and four groups of organisms (O)

\begin{tabular}{lrlrc}
\hline Treatments & $d f$ & Ms & \multicolumn{1}{c}{$F$} & Significance \\
\hline Sites & 4 & $2.05 \times 10^{-7}$ & 5.2 & 0.002 \\
Groups & 3 & $1.14 \times 10^{-8}$ & 29.2 & $<0.001$ \\
$\mathrm{~S} \times \mathrm{G}$ & 9 & $4.2 \times 10^{-6}$ & 1.1 & 0.384 \\
Error & 184 & $3.9 \times 10^{-6}$ & & \\
\hline
\end{tabular}

foliose shapes suffer from different disturbance sources. These forms can be partially covered by sediments which can cause a partial death of nongeniculate coralline red thalli, thereby providing space for other encrusting organisms to settle and to compete with these algae, influencing the formation and growth of the so-called "boxwork" rhodolith structures (Basso 1998). Spherical forms allow rhodoliths to roll and experience the same degree of disturbance on all sides, thus preventing the development of other encrusting organisms. In the studied sites, foliose forms equivalent to the "boxwork" configuration described by Basso (1998) allow rhodoliths to grow sideways.
Aggregation of such rhodoliths with each other forms a stable rhodolith bed which favors the settlement of marine invertebrates. The individual crust is lost in a coalescent process.

Rhodoliths may be entirely composed by one or more species of nongeniculate coralline red algae (Bosence 1983a, b, c; Basso 1998) or may have a core composed by other material ("nucleated rhodoliths"; Freiwald and Henrich 1994), indicating that they can grow from fragments or from spore settlement on a hard substratum (Foster 2001). In the spherical form of studied rhodolith samples, the core and all live surfaces were $100 \%$ composed of nongeniculate coralline red algae. In the foliose forms, the rhodolith core was composed of an assemblage of skeletons of nongeniculate coralline red algae, bryozoans, corals, and mineral substratum. In general, half of the rhodolith dry mass was composed of live encrusting organisms and the other half by a dead core.

The dominant organisms in the outermost rhodolith live layer were the nongeniculate coralline red algae. However, bryozoans, crustaceans (barnacles), and sponges represented an important—but not predominant—component of 
the community, growing as part of this assemblage. There was a significant difference of cover of encrusting organisms on rhodoliths among the studied sites, indicating that the rhodolith bed contains a heterogeneous community structure of encrusting organisms.

Bryozoans, the second most abundant organisms, were observed sharing space with nongeniculate coralline red algae on the surface of foliose rhodoliths. Site 3 was dominated by foliose rhodoliths, on which bryozoans and sessile crustaceans reached their greatest abundance. At the same site, nongeniculate coralline red algae presented the lowest abundance. However, there was no significant correlation between the abundance of nongeniculate coralline red, bryozoans, crustaceans, and sponges in all the studied sites. This result supports the findings of Steller et al. (2003) that rhodolith forms influence directly the diversity and abundance of associated animal taxa.

Bivalve mollusks, corals, and the calcareous red alga Peyssonnelia were the encrusting organisms with lower abundances. The shells of live and dead bivalve mollusks were fixed onto rhodoliths and might be incorporated into the core structure during its formation. Peyssonnelia might connect the structures formed by other organisms, consolidating the rhodolith structure. Corals represent the organisms with least contribution to the live layer of rhodoliths. However, many dead coral fragments were found in the rhodolith core. These may indicate that there was a replacement of the principal builder organism in the community during geological time. Bosence (1983c) observed that taxonomic composition and rhodolith structure can change through time, and these changes can be due to the increase of rhodolith shape or, alternatively, to an ecological succession from the rhodolith core to the outside reflecting a change in the benthic environment. Evidence of the ecological succession theory has been later provided by other authors (Basso and Tomaselli 1994; Basso et al. 1998).

In the studied area, four nongeniculate coralline red algal genera were found forming rhodoliths: Lithophyllum was the dominant genus and is one of the commonest rhodolithforming genera worldwide. Neogoniolithon and Spongites are two other nongeniculate coralline red algae genera that greatly contribute to the composition of this area. These genera have been observed as rhodolith-forming taxa in the Mediterranean (Basso and Rodondi 2006). Neogoniolithon has also been identified as rhodolith-forming genus elsewhere (Riosmena-Rodriguez et al. 2010). Lithothamnion was the genus with lowest frequency, appearing at only two sites of the rhodolith bed, and this is different from elsewhere (Riosmena-Rodriguez et al. 2010). The presence of up to four nongeniculate coralline red algae genera and 7 species demonstrates how diverse the rhodolith beds are.

The genus Lithophyllum is described as one of the commonest rhodolith builders in the world. It is present in both shallow and deep waters presenting a variety of external morphologies (Yabur-Pacheco and RiosmenaRodriguez 2007; Riosmena-Rodriguez et al. 2010). In the Marine Biological Reserve of Arvoredo, southern Brazilian continental shelf, Gherardi (2004) described a small and isolated rhodolith bed composed of only one nongeniculate coralline red algal genus: Lithophyllum. In Manin Bay's Beds, Ireland, Bosence (1979) found two nongeniculate coralline red genera forming rhodoliths: Lithothamnion and Phymatolithon. In the Gulf of California, Steller et al. (2003) found up to three nongeniculate coralline red algal genera: Lithophyllum, Neogoniolithon, and Lithothamnion forming rhodoliths each with one species only, while in our study, we found at least 4 in Lithophyllum and 2 species of Mastophoroids.

The dominance of the foliose rhodolith forms indicates that this is a stable bed. There was no difference in the proportion of live and dead materials within any single rhodolith suggesting that this is an old calcareous deposit. Rhodolith cores are composed of an assemblage of skeletons of nongeniculate coralline red algae, bryozoans, corals, and a mineral substratum, suggesting that the overall rhodolith structure changed through time. The living outer layer of these rhodoliths is somehow similar, built by nongeniculate coralline red algae but associated with a higher number of groups of encrusting organisms. Rhodolith beds in the studied area have a heterogeneous community structure composed by nongeniculate coralline red algae and other encrusting organisms that serve as habitat for many other species, thus forming a complex and diverse environment that needs to be protected. There are other methodologies recently proposed (Leal et al. 2012) who might help in the understanding of rhodolith-forming structures, their associated biodiversity (Riosmena-Rodriguez and Medina-Lopez 2010), and their implications in global change (Basso 2012).

Acknowledgments We are grateful to Petrobras Petroleo S.A. for the doctoral scholarship to the first author. Fundação O Boticário de Proteção à Natureza granted financial research support to the first author. The Botanical Garden of Rio de Janeiro and Universidad Autônoma de Baja California Sur provided laboratory facilities. The Brazilian Research Council (CNPq) and Rio de Janeiro Research Foundation (FAPERJ) provided a visitor research grant. We appreciated the support of the scuba-diving company "Windive" and Luiz Muri, Anderson E. Oliveira, and Frederico T. S. Tâmega for fieldwork assistance. Joel C. Creed kindly revised this English version. We thank the comments from Michael S. Foster, Daniela Basso, and 2 anonymous reviewers who improved our paper with their comments.

\section{References}

Amado-Filho GM, Pereira-Filho GH (2012) Rhodolith beds in Brazil: a new potential habitat for marine bioprospection. Revista Brasileira de Farmacognosia (Impresso) 22:782-788 
Amado-Filho GM, Pereira-Filho GH, Bahia RG, Abrantes DP, Veras PC, Matheus Z (2012a) Occurrence and distribution of rhodolith beds on the Fernando de Noronha Archipelago of Brazil. Aquat Bot 101:41-45

Amado-Filho GM, Moura RL, Bastos AC, Salgado LT, Sumida PY, Guth AZ, Francini-Filho RB, Pereira-Filho GH, Abrantes DP, Brasileiro PS, Bahia RG, Leal RN, Kaufman L, Kleypas JA, Farina M, Thompson FL (2012b) Rhodolith beds are major $\mathrm{CaCO}_{3}$ bio-factories in the tropical south west Atlantic. PLoS ONE 7:e35171

Baarli BG, Santos A, Da Silva CM, Ledesma-Vazquez J, Mayoral E, Cachaño M, Johnson ME (2012) Diverse macroids and rhodoliths from the upper pleistocene of Baja California Sur, Mexico. J Coast Res 28(1):296-305

Bahia RG, Abrantes DP, Brasileiro PS, Pereira-Filho GH, AmadoFilho GM (2010) Rhodolith bed structure along a depth gradient on the northern coast of Bahia State, Brazil. Braz J Oceanogr 58:323-337

Basso D (1998) Deep rhodolith distribution in the Pontian Islands, Italy: a model for the paleoecology of a temperate sea. Palaeogeogr Palaeoclimatol Palaeoecol 137:173-187

Basso D (2012) Carbonate production by calcareous red algae and global change. Geodiversitas 34(1):13-33

Basso D, Tomaselli V (1994) Palaeoecological potentiality of rhodoliths: a Mediterranean case history. In: Matteucci R, Carboni MG and Pignatti JS (eds) Studies on Ecology and Palaeoecology of benthic communities Boll Soc Paleont Ital, Spec vol 2:17-27

Basso D, Rodondi G (2006) A Mediterranean population of Spongites fruticulosus (Rhodophyta, Corallinales), the type species of Spongites, and the taxonomic status of $S$. stalactitica and $S$. racemosa. Phycologia 45:403-416

Basso D, Fravega P, Piazza M, Vannucci G (1998) Biostratigraphic, paleobiogeographic and paleoecological implications in the taxonomic review of Corallinaceae. Rend Fis Acc Lincei 9:201-211

Basso D, Nalin R, Nelson CS (2009) Shallow water Sporolithon rhodoliths from North Island (New Zealand). Palaios 24:92-103

Birkett DA, Maggs C, Dring MJ (1998) Mearl: an overview of dynamic and sensitivity characteristics for conservation management of marine SACs. Scott Assoc Mar Sci (SAMS) 5:1-90

Bosellini A, Ginsburg RN (1971) Form and internal structure of recent algal nodules (rhodoliths) from Bermuda. J Geol 79:669-682

Bosence DWJ (1976) Ecological studies on two unattached coralline algae from Western Ireland. Paleontology 19:365-395, pl. 52-53

Bosence DWJ (1979) Live and dead faunas from coralline algal gravels. Co Galway Palaeontol 22:449-478

Bosence DWJ (1983a) Description and classification of rhodoliths (rhodoids, rhodolites). In: Peryt TM (ed) Coated grains. Springer, Berlin, pp 217-224

Bosence DWJ (1983b) Coralline algal reef frameworks. J Geol 140:365-376

Bosence DWJ (1983c) The occurrence and ecology of recent rhodolits-a review. In: Peryt TM (ed) Coated grains. Springer, Berlin, pp 225-242

Bosence DWJ (1985) The morphology and ecology of a moundbuilding coralline alga (Neogoniolithon strictum) from the Florida Keys. Paleontology 281:189-206

Checconi A, Bassi D, Passeri RR (2006) Coralline red algal assemblage from the Middle Pliocene shallow-water temperate carbonates of the Monte Cetona (Northern Apennines, Italy). Facies 53(1):57-66

Figueiredo MAO, Norton TA, Kain JM (1997) Settlement and survival of epiphytes on two intertidal crustose coralline algae. J Exp Mar Biol Ecol 213:247-260
Foster MS (2001) Rhodoliths: between rocks and soft places. J Phycol 37:659-667

Foster MS, Riosmena-Rodrıguez R, Steller DL, Woelkerling WJ (1997) Living rhodolith beds in the Gulf of California and their implications for paleoenvironmental interpretation. Geol Soc Am Special Paper 318:127-139

Freiwald A, Henrich R (1994) Reefal coralline algal build-ups within the Arctic Circle: morphology and sedimentary dynamics under extreme environmental seasonality. Sedimentology 41:963-984

Gagnon P, Matheson K, Stapleton M (2012) Variation in rhodolith morphology and biogenic potential of newly discovered rhodolith beds in Newfoundland and Labrador (Canada). Bot Mar 55:85-99

Gherardi DFM (2004) Community structure and carbonate production of a temperate rhodolith bank from Arvoredo Island, southern Brazil. Braz J Ocean 52(3/4):207-224

Harvey AS, Bird FL (2008) Community structure of a rhodolith bed from cold-temperate waters (southern Australia). Aust J Bot 56:437-450

James DW, Foster MS, Sullivan JO (2006) Bryoliths (Bryozoa) in the Gulf of California. Pac Sci 60(1):117-124

Kempf M (1970) Notes on the bionomy of the N-NE Brazilian shelf. Mar Biol 5:213-224

Leal Nunes R, Bassi D, Posenato R, Amado-Filho GM (2012) Tomographic analysis for bioerosion signatures in shallow-water rhodoliths from the Abrolhos Bank, Brazil. J Coastal Res 279:306-309

Littler MM, Littler DSL (1984) Relationships between macroalgal functional form groups and substrata stability in a subtropical rocky-intertidal system. J Exp Mar Biol Ecol 74:13-34

Marrack EC (1999) The relationship between water motion and living rhodolith beds in the southwestern Gulf of California. Mexico Palaios 14:159-171

Nelson WA (2012) Online: rhodolith beds in Northern New Zealand: characterisation of associated biodiversity and vulnerability to environmental stressors. Minist Prim Ind, $350 \mathrm{pp}$

Pereira-Filho GH, Amado-Filho GM, de Moura RL, Bastos AC, Guimarães SMPB, Salgado LT, Francini-Filho Ronaldo B, Bahia RG, Abrantes DP, Guth AZ, Brasileiro PS (2012) Extensive rhodolith beds cover the summits of southwestern Atlantic Ocean Seamounts. J Coastal Res 279:261-269

Piller WE, Rasser M (1996) Rhodolith formation by reef erosion in the Red Sea. Egypt Coral Reefs 15:191-198

Prager EJ, Ginsburg RN (1989) Carbonate nodule growth on Florida's outer shelf and its implications for fossil interpretations. Palaios 4:310-317

Reyes-Bonila H, Riosmena-Rodriguez R, Foster MS (1997) Hermatypic corals associated with rhodolith beds in the Gulf of California. Mexico Pac Sci 51:328-337

Riosmena-Rodriguez R, Medina-Lopez MA (2010) The role of rhodolith beds in the recruitment of invertebrate species from the soutwestern Gulf of California, México. In: Israel A (ed) Seaweeds and their role in global changing environments: cellular origin, life in extreme habitats, astrobiology. Springer, Berlin, pp 127-138

Riosmena-Rodriguez R, Woelkerling WJ, Foster MS (1999) Taxonomic reassessment of rhodolith forming species of Lithophyllum (Corallinales, Rhodophyta) in the Gulf of California. Mexico Phycol 38(5):401-417

Riosmena-Rodriguez R, Steller DL, Hinojosa-Arango G, Foster (2010) Reefs that rock and roll: biology and conservation of rhodolith beds in the Gulf of California. In: Bursca RC (ed) Biodiversity and conservation of the sea of Cortez. University of Arizona and Arizona-Sonora Desert Museum Press, USA

Riul P, Lacouth P, Pagliosa PR, Christoffersen ML, Horta PA (2009) Rhodolith beds at the easternmost extreme of South America: 
community structure of an endangered environment. Aq Bot 90:315-320

Sciberras M, Rizzo M, Mifsud JR, Camilleri K, Borg JA, Lafranco E (2009) Habitat structure and biological characteristics of a maerl bed off the northeastern coast of the Maltese Islands (central Mediterranean). Marine Biodivers 39:251-264

Silveira ICA, Schmidt ACK, Campos EJD, Godoi SS, Ikeda Y (2000) A corrente do Brasil ao largo da costa leste brasileira. Braz J Oceanog 48(2):171-183

Sneed ED, Folk RL (1958) Pebbles in the lower Colorado River, Texas A study in particle morphogenesis. J Geol 66:114-150

Steller D, Foster MS (1995) Environmental factors influencing distribution and morphology of rhodoliths in Bahía Concepción, B.C.S, México. J Exp Mar Biol Ecol 194:201-212

Steller DL, Riosmena-Rodríguez R, Foster MS, Roberts C (2003) Rhodolith bed diversity in the Gulf of California: the importance of rhodolith structure and consequences of anthropogenic disturbances. Aquat Conserv Marine Freshwater Ecosyst 13:5-20
Steller DL, Foster, Riosmena-Rodríguez R (2009) Rhodolith banks. In: Jhonson ME, Ledesma-Vázquez J (eds) Atlas of Coastal ecosystems in the Gulf of California. Past and Present University of Arizona Press, USA

Testa V (1997) Calcareous algae and corals in the inner shelf of Rio Grande do Norte, NE, Brazil. In: proceedings of the 8th international coral reef symposium, 737-742

Villas-Boas AB, Figueiredo MAO (2004) Are anti-fouling effects in coralline algae species specific? Braz J Oceanogr 52(1):11-18

Villas-Boas AB, Riosmena-Rodriguez R, Amado-Filho GM, Maneveldt GW, Figueiredo MAO (2009) Taxonomy of rhodolithforming species of Lithophyllum (Corallinales; Rhodophyta) from Espírito Santo State, Brazil. Phycologia 48:237-248

Yabur-Pacheco R, Riosmena-Rodriguez R (2007) Rhodolith bed composition in the Southwestern Gulf of California, México The Nagisa World Congress, 37-47

Zar JH (1984) Biostatistical analysis Prentice-Hall Inc. Englewood Cliffs, New Jersey 718 p 